\title{
Treatment preferences in juvenile idiopathic arthritis - a comparative analysis in two health care systems
}

\author{
Boris Hugle ${ }^{1,2^{*}}$, Susanne M Benseler ${ }^{1}$ \\ From 18th Pediatric Rheumatology European Society (PReS) Congress \\ Bruges, Belgium. 14-18 September 2011
}

\section{Background/aims}

Variations in the treatment of Juvenile Idiopathic Arthritis (JIA) may impact on quality of care. The objective of this study was to identify and compare treatment approaches for JIA in two health care systems.

\section{Methods}

Pediatric Rheumatologists in Canada $(\mathrm{n}=58)$ and Germany/Austria $(n=172)$ were surveyed by email, using case-based vignettes for oligoarthritis and seronegative polyarthritis. Data was analyzed using descriptive statistics; responses were compared using univariate analysis.

\section{Results}

Total response rate was $63 \%$. Physicians were comparable by age, level of training and duration of practice, but more Canadians were based in academic centers. German physicians were more likely to institute DMARD treatment in oligoarthritis refractory to NSAID $(\mathrm{p}<0.001)$, and oral steroid treatment in uveitis $(p=0.043)$. Canadian physicians were more likely to switch to a different DMARD rather than a biologic agent in polyarthritis refractory to DMARD. Both physician groups agreed on time to judge effectiveness of DMARDs (mean 4.2 months) and time to switch to biologic treatment (mean 5.4 months). $86 \%$ and $90 \%$ of German physicians preferred regular physiotherapy over home exercise compared to $14 \%$ and 15\% in Canada for oligoarthritis and polyarthritis, respectively. Except for a Canadian preference for Naproxen in oligoarthritis, no significant differences were found for NSAID,

* Correspondence: boris.hugle@utoronto.ca

'Division of Rheumatology, Hospital for Sick Children, Toronto, Canada

Full list of author information is available at the end of the article intraarticular steroid preparations, initial DMARD and initial biologic treatment.

\section{Conclusion}

Treatment of oligo- and polyarticular JIA with DMARD follows established guidelines, while usage of intraarticular steroids and biologic agents is variable within and between physician groups. Physiotherapy has a fundamentally different role in the two health care systems.

\section{Author details}

'Division of Rheumatology, Hospital for Sick Children, Toronto, Canada.

${ }^{2}$ Pediatric Rheumatology Hospital, Garmisch-Partenkirchen, Germany.

Published: 14 September 2011

doi:10.1186/1546-0096-9-S1-P138

Cite this article as: Hugle and Benseler: Treatment preferences in juvenile idiopathic arthritis - a comparative analysis in two health care systems. Pediatric Rheumatology 2011 9(Suppl 1):P138.

Submit your next manuscript to BioMed Central and take full advantage of:

- Convenient online submission

- Thorough peer review

- No space constraints or color figure charges

- Immediate publication on acceptance

- Inclusion in PubMed, CAS, Scopus and Google Scholar

- Research which is freely available for redistribution 